\title{
Two new remarkable genera and two new species of Gyponini (Hemiptera: Cicadellidae: Iassinae) from Brazil
}

\author{
Alexandre C. DOMAHOVSKI ${ }^{1, *} \&$ Rodney R. CAVICHIOLI ${ }^{2}$ \\ ${ }^{1,2}$ Departamento de Zoologia, Universidade Federal do Paraná, Caixa Postal 19020, \\ 81531-980 Curitiba, PR, Brazil. \\ *Corresponding author: domahovskiac@yahoo.com.br \\ ${ }^{2}$ Email: cavich@ufpr.br \\ ${ }^{1}$ urn:1sid:zoobank.org:author:0B988BD5-599B-42CE-ADCB-50FC813E104E \\ ${ }^{2}$ urn:1sid:zoobank.org:author:58DD5B1D-2A8E-4504-B427-6A6E18E87498
}

\begin{abstract}
The Neotropical fauna of Gyponini is very diverse and still poorly known. Many new species have characters that do not fit with the currently recognized genera, which makes it necessary to propose new ones. Herein, we propose two new Brazilian genera of Gyponini: Acuthana gen. nov., based on A. transgressa gen. et sp. nov. from the State of Mato Grosso, Central-West Brazil and Rectapona gen. nov. based on R. nigrifascia gen. et sp. nov. from the states of Paraná and São Paulo, South and Southeast Brazil, respectively. Diagnosis, detailed description and illustrations of male and female are provided for each taxon, as well as comparisons with closely related genera.
\end{abstract}

Keywords. Acuthana, leafhoppers, morphology, Rectapona, taxonomy.

Domahovski A.C. \& Cavichioli R.R. 2018. Two new remarkable genera and two new species of Gyponini (Hemiptera: Cicadellidae: Iassinae) from Brazil. European Journal of Taxonomy 476: 1-17. https://doi.org/10.5852/ejt.2018.476

\section{Introduction}

The cicadellid subfamily Iassinae Walker, 1870 is distributed worldwide and includes more than 2000 species in 149 genera, which are currently placed in 12 tribes (Dai et al. 2015; Krishnankutty et al. 2016). Species of Iassinae are more diverse and abundant in tropical forests and savannas, with lower diversity in temperate zones (Dai \& Dietrich 2015). However, the Neotropical fauna of Iassinae and its host plants remain poorly known (Dai \& Dietrich 2015; Krishnankutty et al. 2016). Gyponini Stål, 1870 , the largest tribe of Iassinae, is restricted to the New World with $75 \%$ of the genera endemic to the Neotropical Region and 8\% endemic to the Nearctic Region (Nielson \& Knight 2000; Krishnankutty et al. 2016). The tribe can be distinguished from other iassines by the following combination of features: head produced with crown well delimited, ocelli on crown distant from anterior margin and eyes; forewing appendix well developed but not extended around wing apex; hindwing veins $\mathrm{R}_{4+5}$ and $\mathrm{M}_{1+2}$ separate distally; male subgenital plates not completely concealed by pregenital sternite; female first valvula with dorsal sculpturing strigate (Krishnankutty et al. 2016). 
With the recent additions of species, Gyponini now comprises 1388 species in 65 genera (Domahovski \& Cavichioli 2017a, 2017b, 2017c, 2018; Gonçalves et al. 2017, 2018). Specimens can be collected by means of a sweeping net and sometimes yellow plates; however, light and Malaise traps are the most effective methods for collecting. For the Brazilian fauna, 312 species and 36 genera are recorded (Takiya et al. 2018). However, this number probably represents half of the real species number at best, considering the numerous new species awaiting publication, which will account for new country records, plus the high number of specimens representing undetermined species of Gyponini that are deposited in Brazilian entomological collections, many of which do not fit into the currently recognized genera (personal observations).

After analyzing material deposited in the Coleção Entomológica Pe. Jesus Santiago Moure of the Universidade Federal do Paraná, two new species were discovered, for which we propose two new monotypic genera in the tribe: Acuthana gen. nov. from the state of Mato Grosso and Rectapona gen. nov. from the states of Paraná and São Paulo, both described based on male and female specimens.

\section{Material and methods}

The descriptive terminology adopted herein follows mainly Young $(1968,1977)$, except for head features (Hamilton 1981; Mejdalani 1998), wings (Dietrich 2005) and leg chaetotaxy (Rakitov 1997). Usage of the term 'gonoplac' follows Mejdalani (1998). The techniques used for dissection of male genitalia follow Oman (1949), with a few modifications described by Cavichioli \& Takiya (2012).

Label data are specified between quotation marks, with a backslash $(\backslash)$ separating the lines on the labels and a semicolon separating the labels attached to the same specimen. Square brackets ([]) are used to supplement abbreviated information.

The specimens examined in this study were obtained by means of different collection techniques. The holotype and paratype of $A$. transgressa gen. et sp. nov. were collected with a light trap. The specimens of $R$. nigrifascia gen. et sp. nov. were collected with the following traps: the holotype was collected with a Malaise trap suspended at approximately $15 \mathrm{~m}$ above the soil (Fig. 1); the paratype from the state of Paraná was collected with a long cable sweep net, sweeping at approximately $5 \mathrm{~m}$ from the soil, and the paratype from the state of São Paulo was collected with a yellow plate trap.

The specimens are deposited at the Coleção Entomológica Pe. Jesus Santiago Moure, Universidade Federal do Paraná, Brazil, Curitiba (DZUP) and the Museu de Zoologia da Universidade de São Paulo, Brazil, São Paulo (MZSP).
Abbreviations
$\mathrm{AD}=$ anterodorsal
$\mathrm{AV}=$ anteroventral
$\mathrm{PD}=$ posterodorsal
$\mathrm{PV}=$ posteroventral 


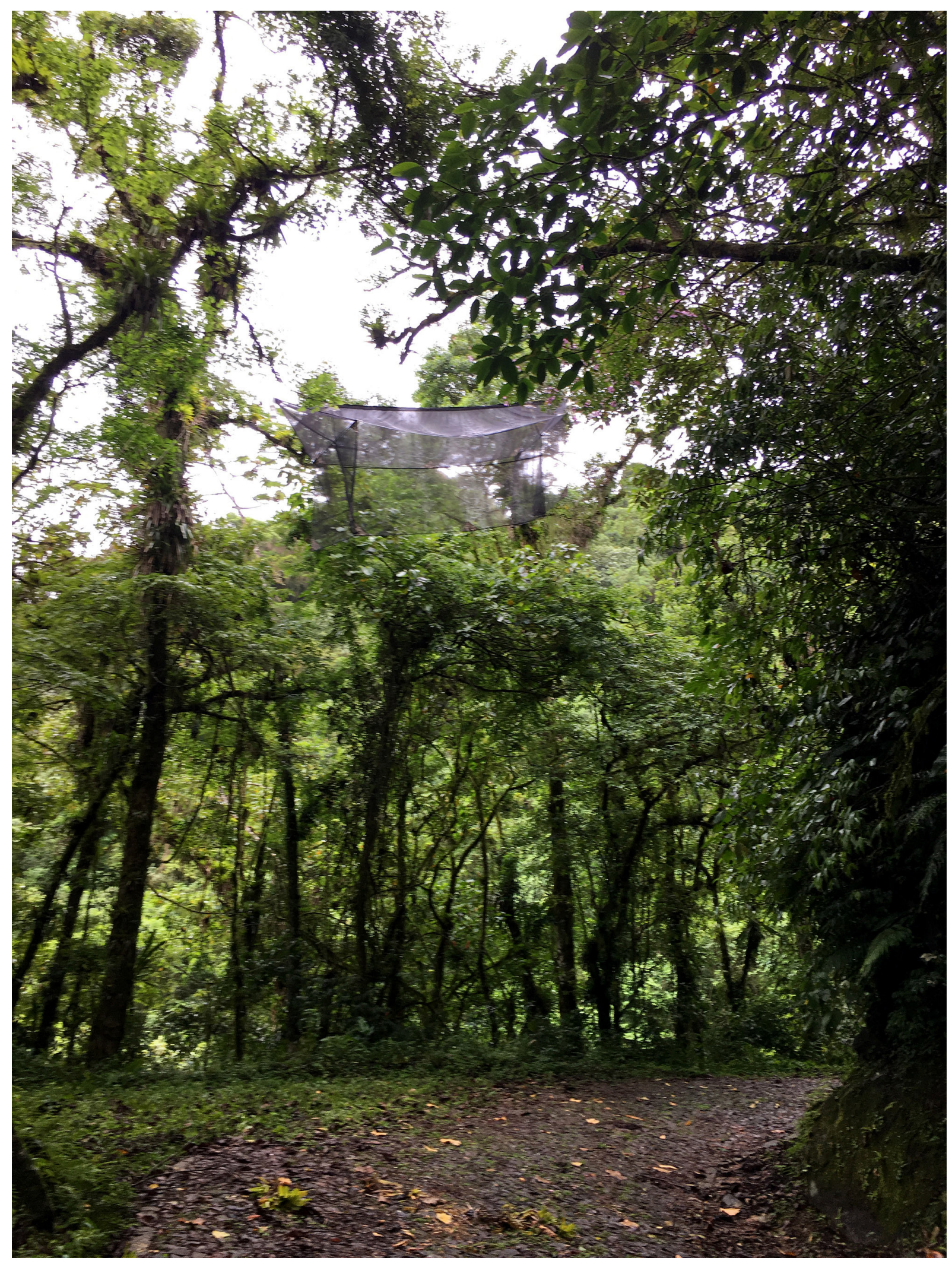

Fig. 1. Malaise trap suspended at approximately $15 \mathrm{~m}$ above the soil, placed near the Guaricana Hydroelectric Plant, Paraná, Brazil. 


\section{Results}

Family Cicadellidae Latreille, 1825

Subfamily Iassinae Walker, 1870

Tribe Gyponini Stål, 1870

Genus Acuthana gen. nov.

urn:1sid:zoobank.org:act:5B8D7B54-084D-4352-897C-F303E8DE6D32

Figs 2-22, 44-45

\section{Type species}

Acuthana transgressa gen. et sp. nov.

\section{Diagnosis}

Head (Fig. 2), with median length of crown slightly less than half interocular width; head surface dorsally with transverse parallel striae; ocelli closer to eyes than to median line and equidistant between anterior and posterior margins of crown; laterally (Fig. 4), with crown-face transition defined with three carinae. Forewing (Fig. 5) anterior half with venation indistinct, heavily punctuated; posterior half distinctly tapered toward apex, venation reticulated. Male with sternite VIII (Fig. 6) triangular ventrally, strongly produced and fully hiding subgenital plates. Aedeagus (Figs 13-14) with atrial processes; dorsal apodeme strongly developed laterodorsally.

\section{Etymology}

The generic name Acuthana, comes from the Latin word 'acutus' and means 'acute'. It refers to the forewing with apical portion distinctly acute. The suffix '-ana' is common in names of other genera of Gyponini.

\section{Description}

MeAsurements. Body length: male $8.7 \mathrm{~mm}$; female $9.0 \mathrm{~mm}$.

HeAd (Figs 2-4). Dorsal view: not produced anteriorly, median length of crown slightly less than half interocular width; crown with anterior margin broadly rounded; surface slightly convex, with transverse parallel striae; transocular width of head nine-tenths humeral width of pronotum; ocelli closer to eyes than to median line and equidistant between anterior and posterior margins of crown; frontal view: face as wide as high; clypeus ca 1.6 times longer than wide, lateral margins parallel, apex straight; maxillary plates produced ventrally as far as clypeus apex; frons as long as wide, flat, not excavated below anterior margin of crown; frontogenal suture not surpassing antennal ledges and distance from eye internal margins equal to maximum clypeus width; antennal ledge carinate and transversal; lateral view: crown-face transition defined, thick, with three clearly defined carinae.

Pronotum (Fig. 2). Transverse striae on disc and posterior third dorsally; lateral margins shorter than eye length, convergent anterad; posterior margin slightly excavated; laterally (Fig. 4) slightly declivous; head and pronotum in continuous slope.

Mesonotum (Fig. 2). Wider than long.

FoREWING (Fig. 5). Anterior half with venation indistinct, heavily punctuated; posterior half distinctly tapered toward apex, venation reticulated; appendix moderately developed. 


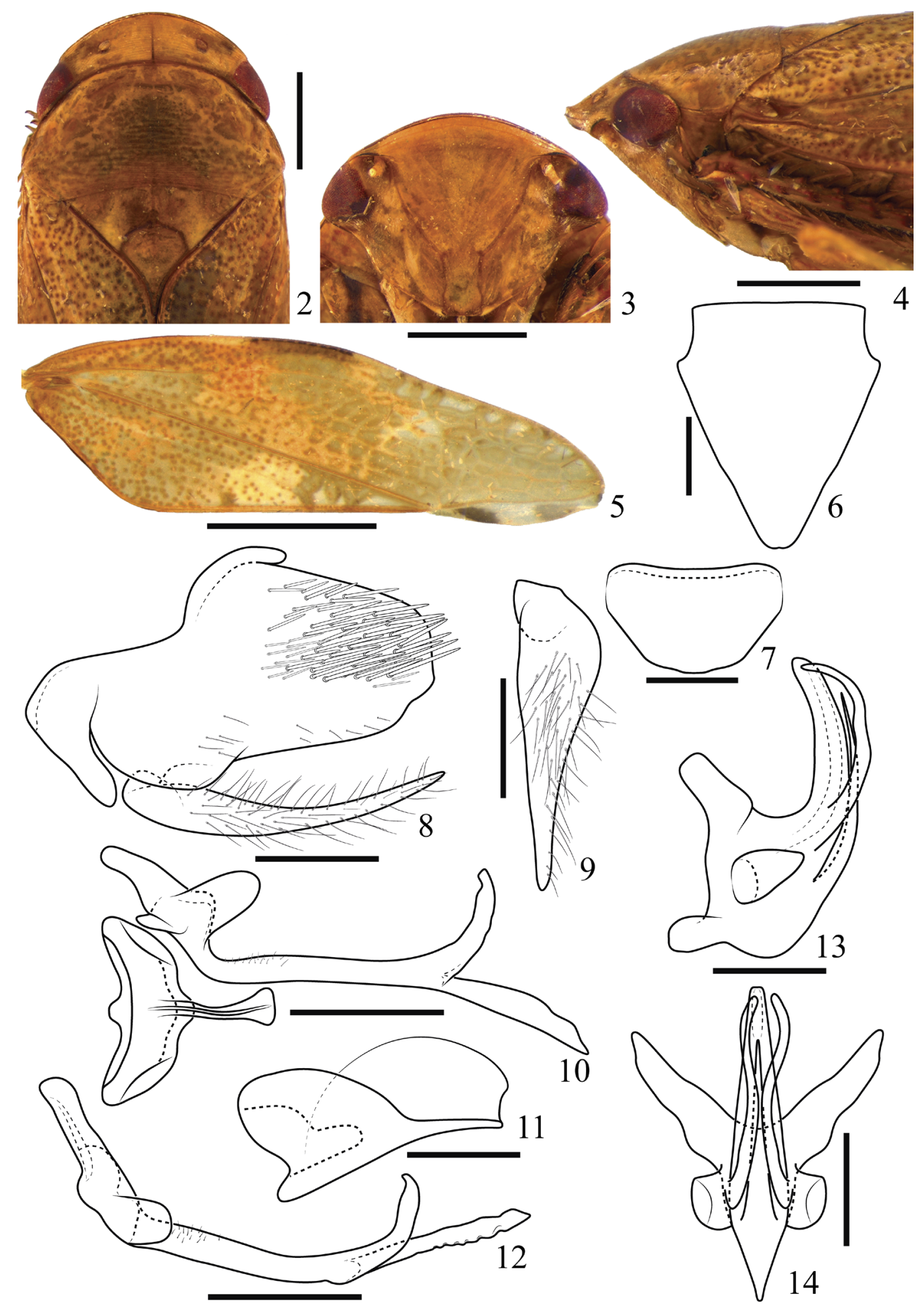

Figs 2-14. Acuthana transgressa gen. et sp. nov., holotype, $\widehat{\jmath}$ (DZUP 215369). 2. Head and thorax, dorsal view. 3. Head, frontal view. 4. Head and thorax, lateral view. 5. Forewing. 6-14. Male terminalia. 6. Sternite VIII, ventral view. 7. Valve, anterior view. 8. Pygofer, valve and subgenital plate, lateral view. 9. Subgenital plate, ventral view. 10. Style and connective, dorsal view. 11. Connective, lateral view. 12. Style, lateral view. 13. Aedeagus, lateral view. 14. Aedeagus, posterior view. Scale bars: $2-4=1.0 \mathrm{~mm}$; $5=2.0 \mathrm{~mm} ; 6-10,12=0.5 \mathrm{~mm} ; 11,13-14=0.25 \mathrm{~mm}$. 
Legs. Profemur four times longer than high; AV row formed by five-six setae and PV row absent; protibia circular-shaped in cross section; AV row formed by short setae in basal half and four-five thick, long setae in distal half; PD row formed by four long setae with some intercalary short setae; PV row developed, with four long setae; metafemur with setal formula 2:2:1; metatibia AD row with intercalary setae between macrosetae; PV row with setae of apical half long and heterogeneous in length and thickness, with long, thick setae followed by four slightly shorter and thinner setae; first tarsomere with outer row of setae absent and inner row formed by approximately nine very short setae, apex with four platellae; second tarsomere apex with two apical platellae.

Male terminalia. Sternite VIII (Fig. 6) triangular, strongly produced and fully hiding subgenital plates. Pygofer (Fig. 8) simple, without processes. In dorsal view, style (Fig. 10) very elongated; outer

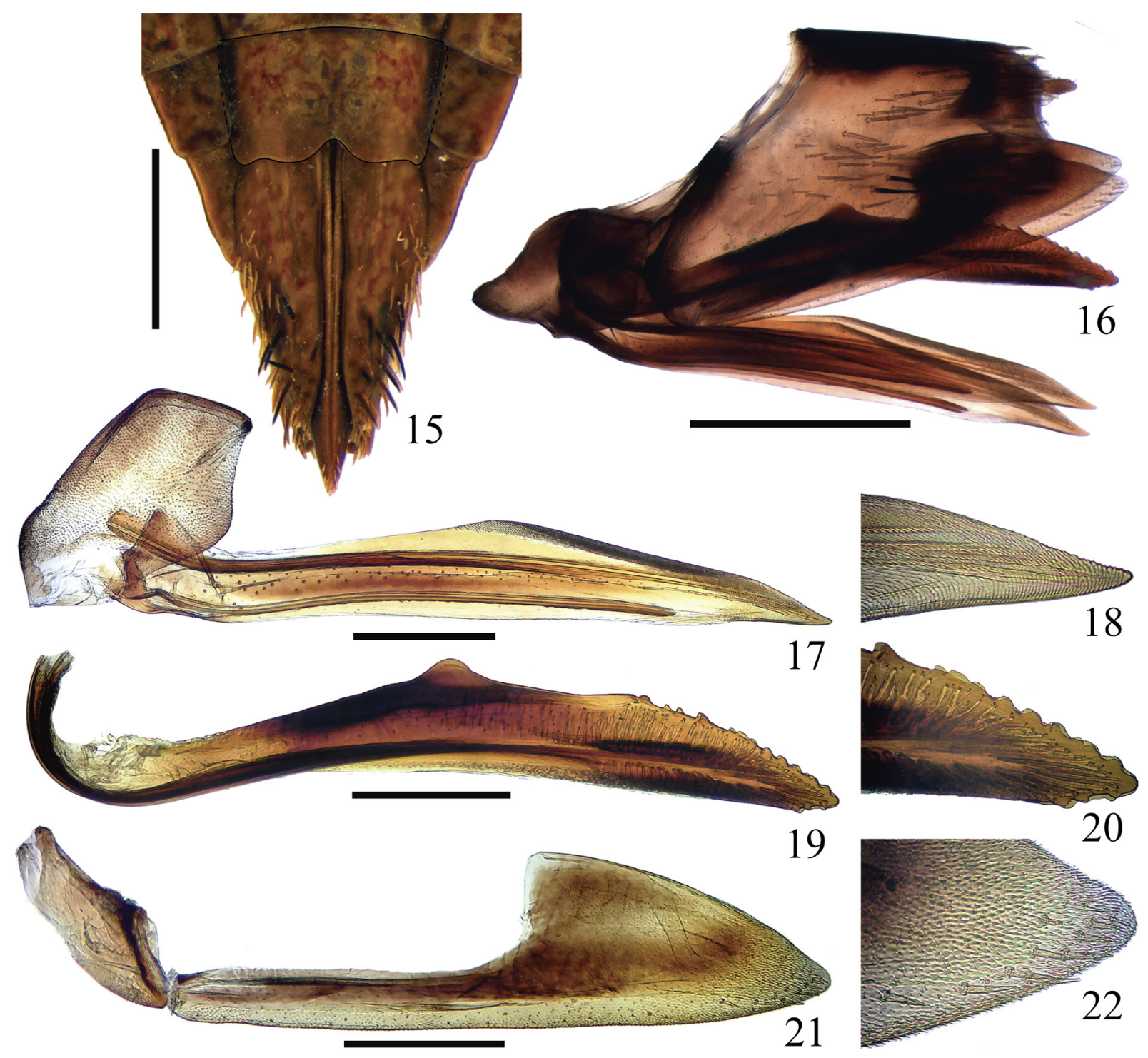

Figs 15-22. Acuthana transgressa gen. et sp. nov., paratype, $q$ (DZUP 215370), terminalia. 15. Sternite VII and pygofer, ventral view. 16. Pygofer and valvulae, lateral view. 17. First valvifer and first valvula, lateral view. 18. Apex of first valvula, lateral view. 19. Second valvula, lateral view. 20. Apex of second valvula, lateral view. 21. Second valvifer and gonoplac, lateral view. 22. Apex of gonoplac. Scale bars: $15-16=1.0 \mathrm{~mm} ; 17,19,21=0.5 \mathrm{~mm} ; 18,20,22=$ not to scale. 
lobe conspicuous. Aedeagus (Figs 13-14) with atrial processes; dorsal apodeme strongly developed laterodorsally.

Female terminalia. Valvulae (Figs 15-16) surpassing pygofer apex. Second valvula (Fig. 19) curved ventrally, very elongated, more than six times longer than maximum height; apical portion (Fig. 20) with irregular teeth on dorsal margin and some small teeth on ventral margin near apex. Gonoplac (Figs 21-22) with short macrosetae near apex.

\section{Distribution}

Brazil (Mato Grosso).

\section{Remarks}

The head of Acuthana gen. nov. is similar to those of Ponana Ball, 1920, Costanana DeLong \& Freytag, 1972, Regalana DeLong \& Freytag, 1975 and Nullana DeLong, 1976, which all have the crown surface with transverse parallel striae and the crown-face transition clearly defined, not rounded as in Polana DeLong, 1942, and with transverse carinae or striae. The new genus is probably more related to Costanana by the shape of the male sternite VIII strongly produced and fully hiding the subgenital plates as in some species (e.g., Costanana cella DeLong \& Freytag, 1972 and Costanana flavina DeLong \& Freytag, 1972) and the shape of the subgenital plate tapered apically with apex acute, which is common in several species of this genus. However, species of Costanana are characterized by the forewings with the basal half of costal margin yellow, aedeagus without atrial processes and aedeagal shaft commonly with apical processes.

The characteristics of the forewing of Acuthana gen. nov. are very unusual. The basal half with many punctuations resembles the forewing of Dragonana Ball \& Reeves, 1927 whereas the presence of reticulations on the apical half similar to Gyponana Ball, 1920 and Chloronana DeLong \& Freytag, 1964. Moreover, the very tapered wing apex is not characteristic of the genera cited. The shape of the female second valvula in Acuthana gen. nov. is very elongated like in species of Costanana. However, most genera of Gyponini, including Costanana, have the second valvula curved dorsally (Fig. 40) or approximately straight, but the new genus differs by the second valvula curved ventrally, which is a highly unusual characteristic in Gyponini.

Acuthana transgressa gen. et sp. nov. urn:lsid:zoobank.org:act:4D49EB9F-BCF4-441E-8BC5-4ED024F970C0

Figs 2-22, 44-45

\section{Diagnosis}

As for genus.

\section{Etymology}

The new species name comes from the Latin word 'transgressus' and means 'crossed'. It refers to the process of both styles, which overlap in dorsal view.

\section{Material examined}

Holotype

BRAZIL: ð’, Central-West Region, Mato Grosso, Sinop, "Brasil Mato Grosso \Sinop X.1975 M. Alvarenga Leg" (DZUP 215369). 


\section{Paratype}

BRAZIL: 1 + , "Brasil, MT, Nova Ubiratã, E.S.E.C. Rio Ronuro, $\backslash 13.1122^{\circ} \mathrm{S}, 54.4436^{\circ} \mathrm{W}, 330 \mathrm{~m} \backslash$ light trap, 11-16.vi.2017, RR\Cavichioli \& AC Domahovski” (DZUP 215370).

\section{Description}

MORPHOLOGY. External morphological characters as in generic description.

Coloration (male and female). Head and thorax (Figs 44-45) yellowish brown. Crown, pronotum and mesonotum (Figs 2, 4) without maculae. Face (Fig. 3) without maculae. Pronotum (Fig. 2) with disk dark-brown. Mesonotum (Figs 2, 45) with lateral angles dark brown. Forewing (Figs 5, 45) yellowishbrown; anterior half opaque with many punctuate dark-brown spots; apex of $2 \mathrm{~A}$ vein, apex of clavus and posterior half of wing dark brown; appendix light yellow with two black maculae on base and midportion. Legs (Figs 44-45) yellowish brown. Foreleg with black maculae on anterior surface near apex.

Male terminalia. Sternite VIII (Fig. 6), triangular, very long, longer than wide; anterolateral angles excavated, posterolateral margins straight; apex narrow and rounded. In ventral view, valve (Fig. 7), 1.6 times as wide as long; integument thickening present only on dorsal margin; ventral margin rounded. Pygofer (Fig. 8), 1.7 times as long as maximum height laterally; anteroventral margin lobed and rounded; apex rounded; macrosetae dispersed on posterodorsal quadrant and some setae near ventral margin. In lateral view, subgenital plate (Fig. 8), produced posteriorly as far as pygofer apex; ventrally (Fig. 9), 3.7 times as long as wide, wider near base and tapered toward apex; setae on ventral surface and external margin; apex very narrow. Connective (Fig. 10) T-shaped dorsally, slightly wider than long; arms wide; stalk very elongate, slightly curved laterally; apex broadened; laterally (Fig. 11), arms wide and high, about half of style length; stalk with translucent and conspicuous keel dorsally. In dorsal view, style (Fig. 10) very elongated, narrow; outer lobe conspicuous and rounded; blade with long process on apical third, narrower than blade on base and wider at mid-length, apex acute directed posteromesad; microsetae present near outer lobe; laterally (Fig. 12), ventral margin not serrated; blade process straight, with some concavities on ventral surface, longer than style apex; apex of blade curved dorsolaterally. Aedeagus (Figs 13-14) with preatrium developed; dorsal apodeme strongly developed dorsolaterally; atrial processes very short, directed posterad; shaft short, flattened laterally, pair of slender and membranous processes at mid-length of shaft, as long as shaft; posterior margin with single process adjacent to shaft, shorter than shaft, apex acute; shaft apex blunt, without processes.

Female terminalia. Sternite VII (Fig. 15) 1.6 times as wide as long; posterior margin slightly excavated near lateral angles and with small V-shaped notch at middle. Sternite VIII membranous. Pygofer(Figs 1516) elongate, about two times as long as maximum height; apex truncated; macrosetae dispersed on posterior half, with some larger macrosetae near ventral margin. First valvifer (Fig. 17) 1.5 times as high as long, anterior and dorsal margins straight, posterior margin rounded. First valvula (Fig. 17) straight; about 7.5 times as long as high; higher at mid-length; gradually tapered toward apex; apex (Fig. 18) acute, sculptured area strigate. Second valvula (Fig. 19) elongated; approximately seven times as long as high; with rounded tubercle at mid-length; apical portion (Fig. 20) with irregular teeth; apex tapered and acute. Gonoplac (Fig. 21) 3.8 times as long as high; ventral margin straight, dorsoapical margin slightly rounded; apex acute. 


\section{Genus Rectapona gen. nov. urn:1sid:zoobank.org:act:2D994B4C-2BDE-4D16-856C-72C6F7652ACB}

Figs 23-43, 46-47

\section{Type species}

Rectapona nigrifascia gen. et sp. nov.

\section{Diagnosis}

Colorful and flattened leafhoppers (Figs 46-47). Head (Fig. 23), with median length of crown half as long as interocular width; crown surface flat, texture with inconspicuous striations, longitudinal striae between ocelli and transverse striae on remaining portion; ocelli small, closer to median line than to eyes and nearer posterior than anterior margin of crown; laterally (Fig. 25), with crown-face transition foliaceous, with two very close carinae. Forewing (Fig. 26) with rectangular shape, costal and anal margins parallel on basal two-thirds. Sternite VIII (Fig. 27) hiding basal half of subgenital plates. Pygofer (Fig. 29) simple, without processes. Aedeagus (Figs 34-35) without atrial processes; preatrium very developed; dorsal apodeme strongly developed laterodorsally.

\section{Etymology}

The generic name Rectapona, comes from the Latin word 'recta' meaning 'straight'. It refers to the unusual shape of the forewing with the costal margin straight. The suffix '-pona' is common in names for genera of Gyponini related to Hecalapona DeLong \& Freytag, 1975.

\section{Description}

Measurements. Body length: male $7.2 \mathrm{~mm}$; female 7.9-8.1 mm ( $\mathrm{n}=2)$.

HEAD (Figs 23-25). Dorsal view: produced anteriorly, median length of crown half as long as interocular width; anterior margin broadly rounded; crown with surface flat, texture with inconspicuous striations, longitudinal striae between ocelli and transverse striae on the remaining portion; transocular width of head eight-tenths humeral width of pronotum; ocelli small, closer to median line than to eyes and closer to posterior margin of crown. Frontal view: with face wider than high; clypeus ca 1.4 times as long as wide, lateral margins parallel, apex straight; maxillary plates very narrow, not produced ventrally as far as clypeus apex; gena with ventrolateral margins not excavate; frons ca 1.4 times longer than maximum width; flat, slightly excavated below anterior margin of crown; lateral margins distant from eye margin as maximum clypeus width; frontogenal suture not reaching anterior margin of crown; antennal ledge carinated and parallel to lateral margin of crown. Lateral view: crown-face transition foliaceous, with two very close carinae.

Pronotum (Fig. 23). Transverse striae on disc and posterior third; lateral margins longer than eye length, convergent anterad; posterior margin slightly excavated; laterally (Fig. 25) rounded and strongly declined anterad; head and pronotum in continuous slope.

Mesonotum (Fig. 23). Wider than long.

Forewing (Fig. 26). Rectangular shape, costal and anal margins parallel on basal two-thirds; with or without extra crossveins on apical or subapical cells; venation distinct; appendix moderately developed bordering first and second apical cells, apex rounded.

LEgs. Profemur four times as long as high; AV row absent and PV row formed by seven-eight setae; protibia triangular-shaped in cross section, dorsal surface flattened and carenate laterally; AV row formed by short setae in basal half and two-three thick and long setae in distal portion; PD row formed by four 


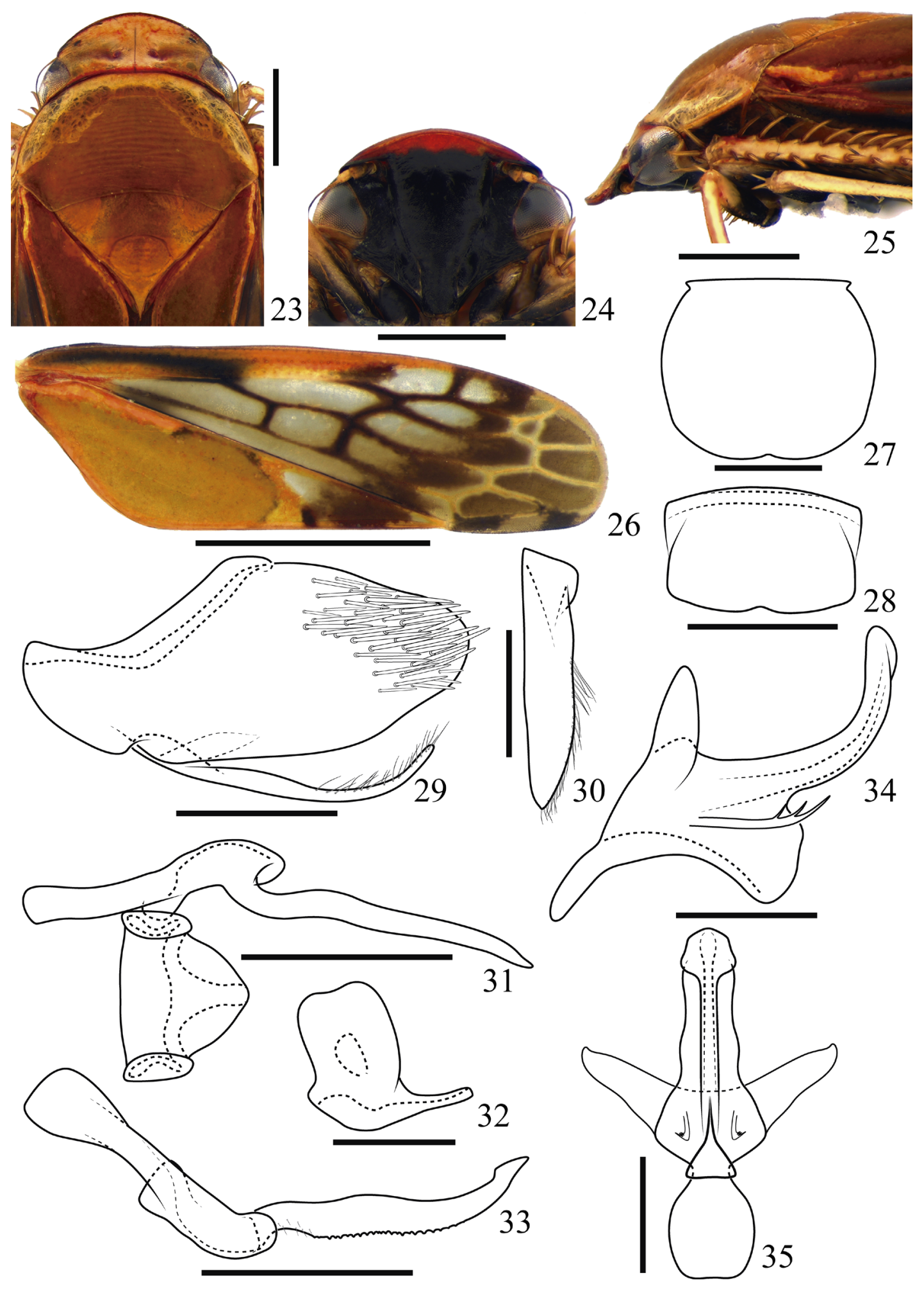

Figs 23-35. Rectapona nigrifascia gen. et sp. nov., holotype, $\widehat{\jmath}$ (DZUP 215371). 23. Head and thorax, dorsal view. 24. Head, frontal view. 25. Head and thorax, lateral view. 26. Forewing. 27-35. Male terminalia. 27. Sternite VIII, ventral view. 28. Valve, anterior view. 29. Pygofer, valve and subgenital plate, lateral view. 30. Subgenital plate, ventral view. 31. Style and connective, dorsal view. 32. Connective, lateral view. 33. Style, lateral view. 34. Aedeagus, lateral view. 35. Aedeagus, posterior view. Scale bars: $23-25=1.0 \mathrm{~mm} ; 26=2.0 \mathrm{~mm} ; 27-31,33=0.5 \mathrm{~mm} ; 32,34-35=0.25 \mathrm{~mm}$. 
very short setae; PV row with only two very short setae at distal half; metafemur with setal formula 2:2:1; metatibia AD row without intercalary setae between macrosetae; PV row with setae of apical half long and thin, homogeneous in length and thickness, except for ticker apical seta; first tarsomere with outer row of setae absent and inner row formed by four very short setae, apex with four platellae; second tarsomere apex with two apical platellae.

Male terminalia. Sternite VIII (Fig. 27) hiding basal half of subgenital plates. Pygofer (Fig. 29) simple, without processes. Aedeagus (Figs 34-35) without atrial processes; preatrium very developed; dorsal apodeme strongly developed laterodorsally.

Female terminalia. Second valvula (Fig. 40) higher near mid-length, with small teeth evanescent posterad, only on dorsal margin. Gonoplac (Fig. 42) without macrosetae.

\section{Distribution}

Brazil (Paraná and São Paulo).

\section{Remarks}

Rectapona nigrifascia gen. et sp. nov. is a colorful leafhopper that probably belongs to the Hecalapona complex, which comprises the following genera: Carapona DeLong \& Freytag, 1975, Hecalapona DeLong \& Freytag, 1975, Hirsutapona Freytag, 2013, Hyperapona Freytag, 2013, Kalopona Freytag, 2015, Nulapona DeLong \& Freytag, 1975, Planipona Freytag, 2015, Sagaripona Freytag, 2015, Spinanella DeLong \& Freytag, 1972 and Versutapona Freytag, 2015 (Freytag 2015). They are easily differentiated from the other genera of Gyponini by the following features: (1) body flattened dorsoventrally; (2) head produced anteriorly with median length of crown approximately half as long as interocular width or longer; (3) crown surface texture smooth, without striations or with inconspicuous striations, which are longitudinal between ocelli and transverse on the remaining portion; (4) crownface transition foliaceous, with two or three carinae; (5) maxillary plates very narrow, not produced ventrally as far as clypeus apex; (6) antennal ledge carinated and parallel to lateral margin of crown; (7) protibia commonly triangular-shaped in cross section; (8) protibia PV row reduced, formed by few setae restricted to distal half. Platypona DeLong, 1982, not included in the Hecalapona complex by Freytag (2015), and the new genus described herein, also have the characteristics listed above. The color of the species of the complex is typically yellowish (green in life), yellowish-orange or greenish, without maculae or with few black maculae. The distribution pattern is mainly tropical with very few species occurring in subtropical areas.

Rectapona gen. nov. is probably more closely related to Platypona (three species described from Peru) and Spinanella (monotypic, from Venezuela), which are the only genera that show elaborated color patterns, also sharing similarities in the structure of the male genitalia. The new genus has the folowing similarities with Platypona: (1) male sternite VIII (Fig. 27) produced posterad, overlapping basal half of subgenital plates; (2) subgenital plate (Figs 29-30) not produced posteriorly as far as pygofer apex; with setae near and on external margin; internal and external margins straight, parallel at base and midportion; apex tapered and subacute; (3) connective (Figs 31-32) with arms broad and directed dorsally. However, Platypona shows the following differences to Rectapona gen. nov.: (1) head more produced anteriorly with median length of crown more than half as long as interocular width; (2) ocelli bigger, located distant from posterior margin of crown and equidistant between median line and eye internal margin; (3) forewing with appendix very narrow; (4) male sternite VIII longer than wide; (5) pygofer with a conspicuous hook-shaped process arising dorsally; (6) style with outer lobe reduced; (7) aedeagus with long atrial processes and aedeagal shaft elongated. 
The aedeagus of Spinanella resembles the new genus genitalia, with preatrium very developed and aedeagal shaft short without apical processes. Spinanella has a pair of long processes arising from the ventral portion of aedeagus closer to preatrium than to the base of shaft, while Rectapona has a single, short and blunt process on shaft base. Besides that, Spinanella has the fowling differences to Rectapona gen. nov.: (1) head more produced anteriorly with median length of crown more than half as long as

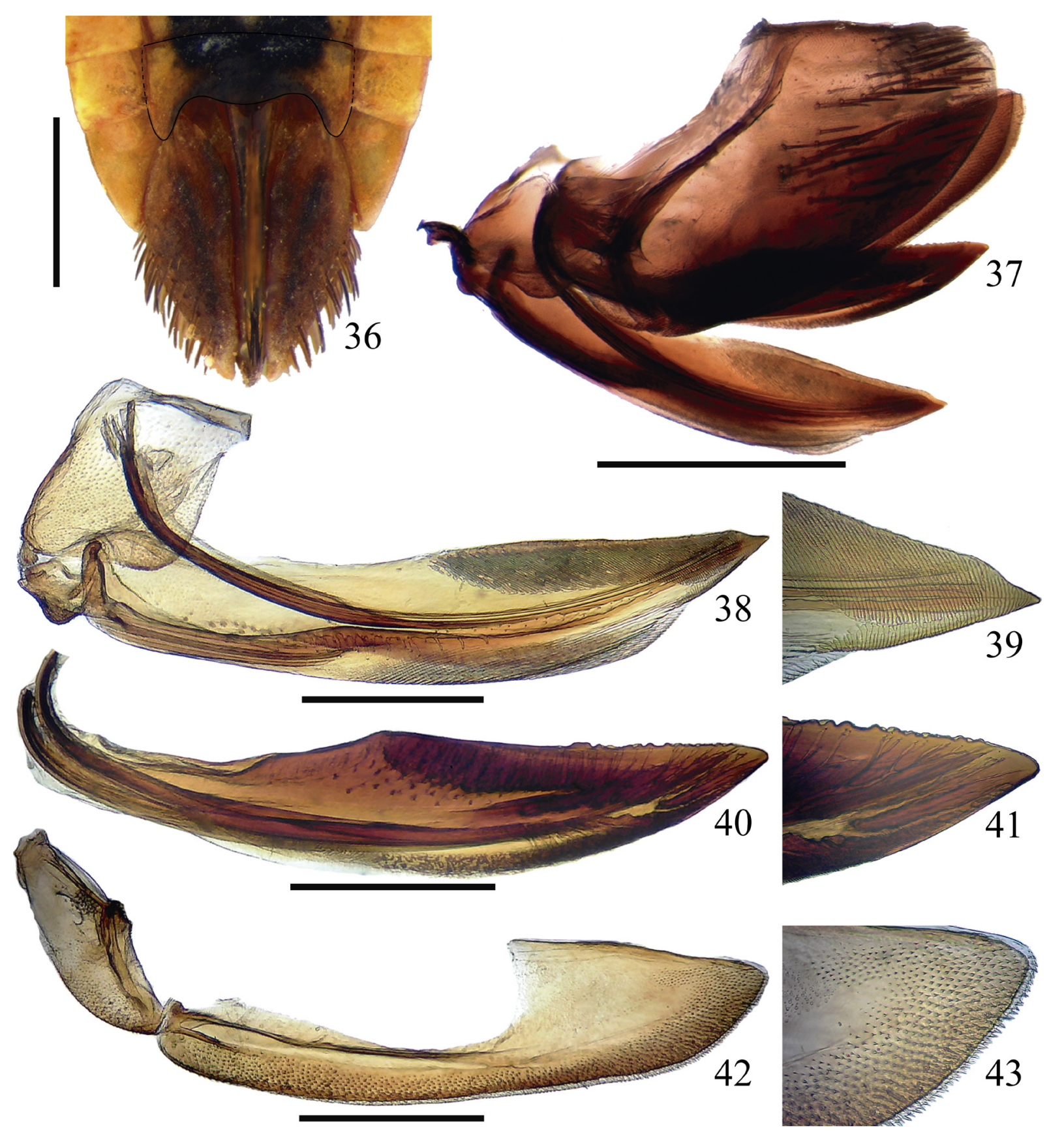

Figs 36-43. Rectapona nigrifascia gen. et sp. nov., paratype, $q$ (DZUP 215372), terminalia. 36. Sternite VII and pygofer, ventral view. 37. Pygofer and valvulae, lateral view. 38. First valvifer and first valvula, lateral view. 39. Apex of first valvula, lateral view. 40. Second valvula, lateral view. 41. Apex of second valvula, lateral view. 42. Second valvifer and gonoplac, lateral view. 43. Apex of gonoplac. Scale bars: $36-37=1.0 \mathrm{~mm} ; 38,40,42=0.5 \mathrm{~mm} ; 39,41,43=$ not to scale. 
interocular width; (2) ocelli distant from posterior margin of crown; (3) pygofer with a conspicuous slender process on posterodorsal margin, more than half length of pygofer, directed posterad; (4) subgenital plate very long and wide, produced posterad as far as the apex of the pygofer process.

Rectapona nigrifascia gen. et sp. nov. urn:1sid:zoobank.org:act:F9BB9E1A-B66D-4AF6-B1D2-80E4278F9EEB

Figs 23-43, 46-47

\section{Diagnosis}

As for genus.

\section{Etymology}

The new species name nigrifascia comes from the Latin term 'nigro faciem'. It refers to the black coloration of the face.

\section{Material examined}

Holotype

BRAZIL: Ō, South Region, Paraná, São José dos Pinhais, "Brasil, PR, S.[São] J. [José] dos Pinhais\ Rep. [Represa] Guaricana, Malaise susp. [suspensa] 25.7305 S 48.9535 $\mathrm{W}, 495 \mathrm{~m} \backslash$ 01-20.II.2018, Muniz, Melo $\backslash$ Cavichioli \& Domahovski” (DZUP 215371).

\section{Paratypes}

BRAZIL: 1 q, "Brasil, Paraná, Morretes $\backslash$ P. [Parque] E. [Estadual] do Marumbi, cami- $\backslash$ nho para Estação

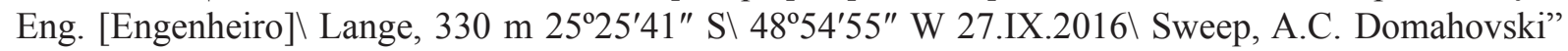
(DZUP 215372); 1 क , "Brasil, SP, Ubatuba, $\backslash$ Parque Estadual da $\backslash$ Serra do Mar YPT [Yellow plate trap] $23^{\circ} 17^{\prime} 49^{\prime \prime} \mathrm{S} 44^{\circ} 47^{\prime} 31^{\prime \prime} \mathrm{W} \backslash 800 \mathrm{~m}$ 21.II-2.III.2007 E. F. Santos \& C. P. Scott” (MZSP).

\section{Description}

Morphology. External morphological characters as in generic description.

\section{Male}

Coloration. Crown (Fig. 23) yellow, tinged with red; anterior and posterior margins red. Face (Fig. 24) black; lora margined with yellow; gena yellowish below ventral margin of eye; frons with a transversal red stripe below crown margin; antenna yellow. Pronotum (Fig. 23) golden-yellow; lateral and anterior margins yellow; laterally (Fig. 25), proepimeron black with dorsal margin yellow. Mesonotum (Fig. 23) golden-yellow. Forewing (Fig. 26) clavus opaque; basal portion greenish-yellow margined with yellow; apex of 1A vein dark-brown; apex dark-brown; corium translucent with black veins on basal portion and white veins on apical portion; costal margin golden-yellow with a longitudinal black stripe from wing base to base of external discal cell; apical half of subapical cells and apical cells dark-brown; appendix dark-brown with base and apex black. Legs (Fig. 46) with coxae black; femurae black with apex yellow; pro and mesotibiae yellow; meta tibia yellow with distal half black, except dorsal surface; tarsomeres yellow, exept hind leg tarsomeres black with apex of third tarsus and pretarsus yellow. Abdome with dorsum red with lateral margins of each terguite black; venter black with laterotergite III orange, posterior margin of each laterotergite and sternite yellowish-orange, sternite VIII entirely black.

Terminalia. Sternite VIII (Fig. 27) 1.2 times as wide as long, hiding basal half of subgenital plates; lateral margins rounded; posterior margin emarginated. Valve (Fig. 28) rectangular, 1.5 times as wide as long; integument thickening present only on dorsal margin; ventral margin emarginated. Pygofer (Fig. 29) simple, without processes, about 1.8 times as long as maximum height laterally; integument 
thickening present parallel to anterodorsal margin and continuous with the integument thickening of valve; ventral margin straight; posterodorsal and posteroventral margins slightly convergent posterad; apex rounded. In lateral view, subgenital plate (Fig. 29), not produced posteriorly as far as pygofer apex; apex curved dorsally; ventrally (Fig. 30) elongated, five times as long as wide, with setae on dorsal surface near and on external margin; internal and external margins straight, parallel on base and mid-portion; apex tapered and subacute. Connective (Fig. 31) triangular dorsally, wider than long; arms wide; stalk two times as wide as long; apex tapered; laterally (Fig. 32) arms curved dorsally; stalk flat. In dorsal view, style (Fig. 31) with outer lobe small, rounded; laterally (Fig. 33) elongate, with apodeme as long as blade; ventral margin serrated medially, approximately same height along its entire length; apex acute, curved dorsally. Aedeagus (Figs 34-35) with preatrium strongly developed, laterally constricted at base; dorsal apodeme strongly developed dorsolaterally; atrial processes absent; shaft short, flattened dorsoventrally, a pair of slender processes near base, directed posterad, with two subapical spine-like
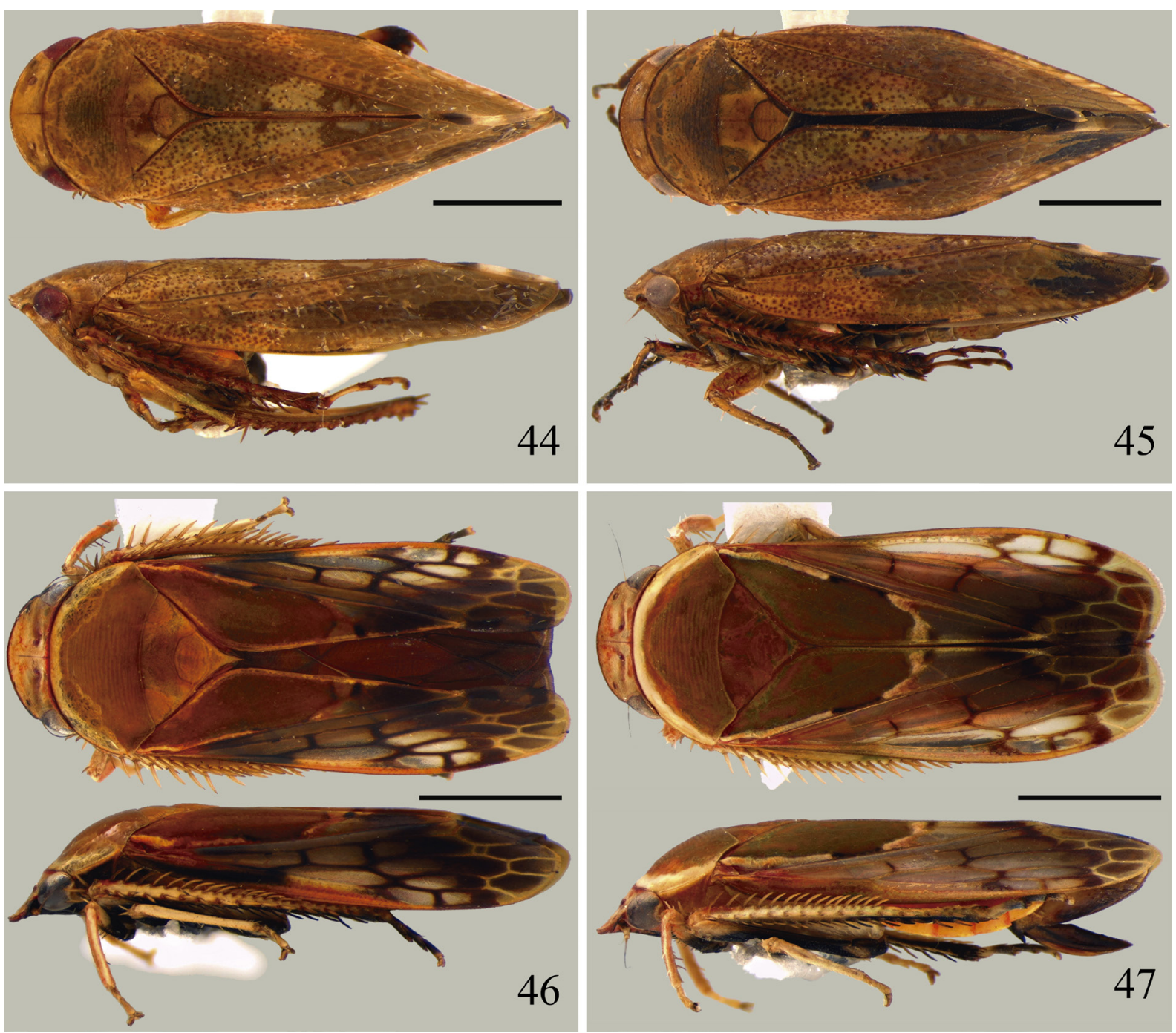

Figs 44-47. Type material, habitus. 44-45. Acuthana transgressa gen. et sp. nov. 44. Holotype, Љ (DZUP 215369), dorsal view (upper) and lateral view (lower). 45. Paratype, $q$ (DZUP 215370), dorsal view (upper) and lateral view (lower). 46-47. Rectapona nigrifascia gen. et sp. nov. 46. Holotype, $\widehat{\delta}$ (DZUP 215371), dorsal view (upper) and lateral view (lower). 47. Paratype, $q$ (DZUP 215369), dorsal view (upper) and lateral view (lower). Scale bars: $2.0 \mathrm{~mm}$. 
processes on dorsal margin; ventral margin near base with a single short, robust process with blunt triangular apex, directed posterad; shaft apex rounded, without processes.

\section{Female}

Coloration. Pronotum (Fig. 47) with proepimeron golden-yellow with dorsal margin yellow. Face black; gena yellowish-orange around eye; frons with a transversal orange stripe below crown margin and frontogenal suture. Forewing (Fig. 47) with corium with veins yellow on basal portion of wing, except by cross veins of discal cells dark-brown; costal margin greenish-yellow without longitudinal black stripe from wing base to base of external discal cell. Hind leg tarsomeres grey with base of first and apex of third tarsus and pretarsus yellow. Abdomen with dorsum orange with lateral margins of each terguite yellow; venter (Fig. 36) yellow with sternites III to VII with mid-portion black; pygofer brown. Other colorations as in male description.

Terminalia. Sternite VII (Fig. 36) 1.8 times as wide as long; lateral angles rounded; posterior margin excavated laterad of broad median lobe, which occupies median third and is not produced posteriorly as far as lateral angles. Sternite VIII membranous. Pygofer (Figs 36-37) short, about 1.7 times as long as maximum height; apex rounded; macrosetae dispersed on posterior half. First valvifer (Fig. 38) 1.2 times as high as long, anterior, dorsal and posterior margins straight; posteroventral corner rounded. First valvula (Fig. 38) wide, slightly curved dorsally; about 5.1 times as long as high; same height along its entire length; apex (Fig. 39) tapered, with sculptured area strigate; apex acute. Second valvula (Fig. 40) 4.8 times as long as high; higher near mid-length; apical portion (Fig. 41) dorsal margin with small teeth evanescent posterad; apex acute. Gonoplac (Fig. 42) 3.8 times as long as high, only with microsetae; ventral and dorsoapical margins straight; posteroventral margin rounded; apex (Fig. 43) subacute.

\section{Remarks}

Some polymorphism in the forewing venation was observed in the studied specimens: the holotype has an extra crossvein on base of the forth apical cell of both wings; the paratype from the state of Paraná has an extra crossvein on the apex of the inner anteapical cell of the left wing and the paratype from the state of São Paulo does not have extra crossveins.

\section{Discussion}

Gyponini is the largest tribe of Iassinae, and based on the large amount of undescribed new species from Brazil, this tribe could easily represent one of the largest tribes of Cicadellidae. According to Krishnankutty et al. (2016), one of the diagnostic characteristics of the Gyponini is the male subgenital plate not completely concealed by the sternite VIII. However, although this applies for most of the species, some of them differ from the diagnosis in having the sternite VIII very produced posteriorly, completely hiding the subgenital plates, as observed in Acuthana gen. nov. as well as some species of Costanana and Polana.

The two new species described herein show a different combination of features from those present in the currently recognized genera, which makes it necessary to propose two new genera to include them. A. transgressa gen. et sp. nov. differs from the other genera of Gyponini by the anterior half of forewing with venation indistinct, heavily punctuated; posterior half distinctly tapered toward apex, with reticulated veins; male sternite VIII very produced and fully hiding the subgenital plates. Rectapona gen. nov. belongs to the Hecalapona genera complex and is described based on $R$. nigrifascia gen. et sp. nov. It differs from the other genera by the body with a colored pattern; head produced with median length of crown half as long as interocular width; ocelli small, nearer to the posterior margin than anterior margin of crown; forewing with rectangular shape; pygofer simple, without processes; aedeagus without atrial processes and with preatrium highly developed. 
Further taxonomic work is still needed for the Gyponini, considering only a few generic revisions are available and mostly outdated. Furthermore, descriptions of new genera and species may unveil new characters useful for phylogenetic reconstructions based on morphological data.

\section{Acknowledgements}

We thank the Conselho Nacional de Desenvolvimento Científico e Tecnológico (CNPq) for fellowships provided to A.C. Domahovski (process 140815/2017-1) and R. R. Cavichioli (process 305484/2014-1). Our gratitude is extended to two anonymous reviewers who kindly made improvements to a preliminary version of this manuscript. We would also like to thank Fernando Cesar Alves da Silva Ferreira for the license to place the Malaise traps at the Guaricana Hydroelectric Plant. This paper is contribution number 1957 of the Departamento de Zoologia, Universidade Federal do Paraná.

\section{References}

Cavichioli R.R. \& Takiya D.M. 2012. Description of a new species of Wolfniana and new records of Rotigonalia (Hemiptera: Cicadellidae: Cicadellinae) from the state of Amazonas, Brazil. Zoologia 29 (1): 85-88. https://doi.org/10.1590/S1984-46702012000100011

Dai W. \& Dietrich C.H. 2015. A new genus of Iassinae (Hemiptera: Cicadellidae) from Peru and a new species of Daveyoungana Blocker \& Webb. Zootaxa 3946 (2): 285-295. https://dx.doi.org/10.11646/zootaxa.3946.2.10

Dai W., Dietrich C.H. \& Zhang Y. 2015. A review of the leafhopper tribe Hyalojassini (Hemiptera: Cicadellidae: Iassinae) with description of new taxa. Zootaxa 3911 (1): 1-42.

https://dx.doi.org/10.11646/zootaxa.3911.1.1

Dietrich C.H. 2005. Keys to the families of Cicadomorpha and subfamilies and tribes of Cicadellidae (Hemiptera: Auchenorrhyncha). Florida Entomologist 88: 502-517.

https://doi.org/10.1653/0015-4040(2005)88[502:KTTFOC]2.0.CO;2

Domahovski A.C. \& Cavichioli R.R. 2017a. Six new Brazilian species of Polana (Varpulana) (Hemiptera: Cicadellidae: Gyponini) with key to males. Zootaxa 4244 (4): 535-555.

https://doi.org/10.11646/zootaxa.4244.4.5

Domahovski A.C. \& Cavichioli R.R. 2017b. Two new species of Nullana from southern Brazil (Hemiptera: Cicadellidae: Gyponini) with key to males. Zootaxa 4281 (1): 207-218.

https://doi.org/10.11646/zootaxa.4281.1.19

Domahovski A.C. \& Cavichioli R.R. 2017c. Two new species of Kalopona (Hemiptera: Cicadellidae: Gyponini) from Brazil. Zootaxa 4323 (4): 586-592. https://doi.org/10.11646/zootaxa.4323.4.11

Domahovski A.C. \& Cavichioli R.R. 2018. Two new species of Polana (Hobemanella) (Hemiptera: Cicadellidae: Gyponini) and key to species. Zoologia 35 (e13882): 1-8.

https://doi.org/10.3897/zoologia.35.e13882

Freytag P.H. 2015. Four new genera and nine new species related to the genus Hecalapona (Hemiptera: Cicadellidae: Gyponinae). Entomological News 124 (4): 245-264. https://doi.org/10.3157/021.124.0402

Gonçalves C.C., Takiya D.M. \& Mejdalani G. 2017. Sakakibarana, a new genus of Gyponini (Hemiptera: Cicadellidae: Iassinae) from the Amazon Rainforest. Zootaxa 4281 (1): 219-224. https://doi.org/10.11646/zootaxa.4281.1.20

Gonçalves C.C., Takiya D.M. \& Mejdalani G. 2018. Two new species of Polana (Hemiptera: Cicadellidae: Iassinae: Gyponini) and redescription of Polana (Striapona) desela. Zootaxa 4457(1): 143-155. https://doi.org/10.11646/zootaxa.4457.1.7 
Hamilton K.G.A. 1981. Morphology and evolution of the Rhynchotan head (Insecta: Hemiptera, Homoptera). Canadian Entomologist 113: 953-974. https://doi.org/10.4039/Ent113953-11

Krishnankutty S.M., Dietrich C.H., Dai W. \& Siddappaji M.H. 2016. Phylogeny and historical biogeography of leafhopper subfamily Iassinae (Hemiptera: Cicadellidae) with a revised tribal classification based on morphological and molecular data. Systematic Entomology: 1-16. https://doi.org/10.1111/syen.12175

Mejdalani G. 1998. Morfologia externa dos Cicadellinae (Homoptera, Cicadellidae): comparação entre Versigonalia ruficauda (Walker) (Cicadellini) e Tretogonia cribrata Melichar (Proconiini), com notas sobre outras espécies e análise da terminologia. Revista Brasileira de Zoologia 15: 451-544. https://doi.org/10.1590/S0101-81751998000200015

Nielson M.W. \& Knight W.J. 2000. Distributional patterns and possible origin of Cicadellidae). Revista Brasileira de Zoologia 17: 81-156. https://doi.org/10.1590/S0101-81752000000100010

Oman P.W. 1949. The Nearctic leafhoppers (Homoptera: Cicadellidae). A generic classification and check list. Memoirs of the Entomological Society of Washington 3, Entomological Society of Washington, Washington DC.

Rakitov R.A. 1997. On differentiation of cicadellid leg chaetotaxy (Homoptera: Auchenorrhyncha: Membracoidea). Russian Entomological Journal 6: 7-27.

Takiya D.M., Cavichioli R.R., Mejdalani G., Felix M., Gonçalves C.C., Camisão B.M. \& Barbosa J.F. 2018. Cicadellidae in Catálogo Taxonômico da Fauna do Brasil. PNUD. Available from http://fauna.jbrj.gov.br/fauna/faunadobrasil/5020 [accessed 9 Aug. 2018].

Young D.A. 1968. Taxonomic study of the Cicadellinae (Homoptera: Cicadellidae). Part 1. Proconiini. Bulletin of the United States National Museum 261: 1-287. https://doi.org/10.5962/bhl.part.20869

Young D.A. 1977. Taxonomic study of the Cicadellinae (Homoptera: Cicadellidae). Part 2. New World Cicadellini and the genus Cicadella. Bulletin of North Carolina Agricultural Experiment Station 239: $1-1135$.

Manuscript received: 26 June 2018

Manuscript accepted: 24 August 2018

Published on: 15 November 2018

Topic editor: Gavin Broad

Section editor: Anna Namyatova

Desk editor: Chloë Chester

Printed versions of all papers are also deposited in the libraries of the institutes that are members of the EJT consortium: Muséum national d'Histoire naturelle, Paris, France; Botanic Garden Meise, Belgium; Royal Museum for Central Africa, Tervuren, Belgium; Natural History Museum, London, United Kingdom; Royal Belgian Institute of Natural Sciences, Brussels, Belgium; Natural History Museum of Denmark, Copenhagen, Denmark; Naturalis Biodiversity Center, Leiden, the Netherlands; Museo Nacional de Ciencias Naturales-CSIC, Madrid, Spain; Real Jardín Botánico de Madrid CSIC, Spain; Zoological Research Museum Alexander Koenig, Bonn, Germany. 